\title{
Foxy Business
}

Although British broadcasting is mercifully free from the strident editorialising which characterises most of the British press, it hasn't always escaped charges of bias. Back in the days when media studies still had a critical edge, books such as The Manufacture of News, Putting 'Reality' Together and the various Bad News studies from the Glasgow University Media Group argued that broadcast news and current affairs programmes, for all their apparent impartiality and balance, actually presented a largely establishment-friendly view of the world. More recently this charge has been taken up by radical journalists such as John Pilger and Nick Cohen, and it's a constant theme of Noam Chomsky's formidable output

Now the question of impartiality has been raised by rather less radical commentators in the shape of Damian Tambini and Jamie Cowling in New News: Impartial Broadcasting in the Digital Age, a collection which they edited for the Institute for Public Policy Research, and Ian Hargreaves and James Thomas in New News, Old News, an account of research undertaken for the Broadcasting Standards Commission and Independent Television Commission.

Why this renewed interest? Well, according to Tambini: 'despite the success of the British approach to impartiality in broadcasting, the regulations that guarantee it will have to change if the UK traditions of independent, accurate, impartial broadcasting are to survive'. The need for reform arises both from changes to the broadcasting ecology and wider political shifts: 'the market is fragmenting and becoming more competitive whilst commercial concerns are tainting the news values of all broadcasters. At the same time, politics is changing in ways that challenge UK news regulation, focused as it is on a narrow range of party balance'.

On the broadcasting front, increased competition has meant, according to Tambini, that: "news is increasingly presented to attract an audience, rather than to reflect formal notions of the public interest and impartiality'. This is not something that the IPPR authors welcome, rather they although acknowledge it as a challenge to be faced. Additionally, they also recognise that it may become increasingly difficult, although not impossible, for OFCOM to enforce impartiality regulations for a plethora of channels, including foreign language and niche channels, some of which are not even aimed at UK audiences.

Turning to the political aspect of the question, Tambini argues that: 'we no longer live in a bipolar world. Political motivations and organisations are more complex than ever, and newer political 
problems involving science, the calculation of ecological risk and the opposition between fundamentalism and liberalism replace the older issues of capital versus labour that "impartiality" regulation was designed to manage. The Left-Right axis of politics is in decline. The share of the vote enjoyed by the two main parties has declined, and single-issue movements have emerged as more active players'. Thus impartiality codes designed essentially to ensure fair treatment between the two major established political parties are ill-suited to dealing with political issues in an era in which, for an increasing number of people, the play of forces at Westminster no longer constitutes what they regard as politics. This has meant, among other things, that questions are now increasingly being asked about the media filters through which the UK public experience their political life. Tambini sums up these concerns by asking: 'is regulation for broadcasting impartiality responsible for a ritualised, adversarial presentation of politics that in fact contributes to public disengagement?', and he and Cowling conclude that, partly thanks to these rules: 'we are illprepared to cope with the complexity of politics in the new century, and the institutions of impartiality regulation run the risk of becoming irrelevant or, worse, obliging journalists to focus on ritualised formal politics when the real story, and the real challenge for public information, is elsewhere'.

Broadcasting's apparent inability to deal adequately with a changed political environment, and the role played by current impartiality regulations in this shortcoming, also concern New News, Old News. This reports that the overall level of television national news consumption has fallen by $5.6 \%$ since 1994, in spite of an $80 \%$ increase of supply on the five main terrestrial channels. ITV has experienced a $23 \%$ decline, and the biggest fall-offs in viewing (14\%) have been among the 2534 age group and social groups C2DE. People are increasingly 'spotlight chasing' - dipping into 24-hour news channels when a major story such as $9 / 11$ breaks - or using the Internet. Only $16 \%$ of those questioned regarded themselves as regular current affairs viewers, and between 1994 and 2002 the current affairs audience fell by $31.7 \%$ whilst current affairs output dropped by almost $12 \%$.

On the other hand, however, $92 \%$ of those who took part in the survey thought that the principle of accuracy in news was very important, and $71 \%$ took the same view about impartiality. Interestingly, $88 \%$ of those in multi-channel homes thought impartiality a good thing, compared to 93\% in non-multi-channel homes. The Report states that this particular finding adds weight to 'the view that there may be the first signs of a growing volume of dissent from this long-established principle as viewers enjoy greater choice. This may be an early warning sign that Parliament and regulators should be ready to understand and respond to a shifting view and to encourage 
innovation rather than stifle it'. It's also significant that only $64 \%$ of those among the Asian and black communities thought impartiality a good thing, 'perhaps reflecting a view amongst these communities that broadcast news is not impartial in its reporting of issues of concern to them'.

In what ways, then, do the authors of these studies think that the impartiality regulations might be changed in order to meet some of the concerns which they raise? According to Tambini and Cowling, the BBC, ITC and Radio Authority codes should encourage a broader approach to balance, one that does not necessarily require a focus on each major party's stance on every issue. In particular: 'a greater emphasis should be placed on the need for impartiality in relation to a range of expert opinions, the problem of corporate interests, single-issue groups, and competing scientific opinions'. In their view: 'the provision of accurate, impartial news to the citizen and the requirement for due impartiality should be retained for all broadcast services which are not an active purchase ... The principles guiding content regulation in general are that the services that are most public, most invasive, most pervasive and most influential should be subject to most regulation in the public interest. As the market develops for niche services, OFCOM should be periodically consult the public on whether to relax the impartiality obligations on those services with less market share'. What this in effect means is that: 'there will be a role in the future for polemical channels. It is possible that polemical channels, if correctly regulated, could widen the diversity of voice in British broadcasting'.

Hargreaves and Thomas reach broadly similar conclusions, arguing that: 'in a time of diminished party loyalties, impartiality should be more broadly defined, to require that broadcasters provide even-handed treatment of issues of race, science, environment, health and any other matter of public controversy'. However, they explicitly reject relaxations of the impartiality regulations based on the notion of 'active purchase' because (a) in the digital future, so many channels are likely to be 'active purchases', and (b) they feel it unclear 'what amounts to an "active purchase" in a satellite television environment, where services are bundled together for sale to consumers'.

Nonetheless, given that their survey shows that significant numbers of the young and of Britain's ethnic groups feel that broadcast news does not represent them adequately, 'it may be that a more opinionated style of broadcast news, originated from well outside the UK broadcasting mainstream, is helpful in the overall news mix, so long as consumers are aware what they are getting and which services conform to impartiality rules and which do not. The time has come when a range of experimentation should be encouraged'. In their view, therefore, 'the most sensible course is to create an opening for OFCOM to recommend to the Secretary of State variation in the impartiality 
rules, where channels involved are of minority interest and where they do not threaten the central, impartial reputation of mainstream UK television news'.

It's unfortunate, to put it mildly, that such thoughtful analyses of the political shortcomings of news and current affairs programmes should conclude with recommendations that are guaranteed only to make matters considerably worse. Why? Because they will simply allow Murdoch to do to British broadcasting what he has already done to the British press: namely, force all other market players to compete with him on his own debased terms. For Murdoch is absolutely itching to turn Sky News into a British version of his rabidly populist Fox News which, even before its post 9/11 transformation into a cheerleader for war, was dubbed by Freedom and Accuracy in Reporting (FAIR) 'the most biased name in news'. Asked by the New York Times whether Sky would be imitating Fox, Murdoch replied: 'I wish. I think that Sky News is very popular and they are doing very well, but they don't have the entertaining talk shows - it is just a rolling half-hour of hard news all the time'. The paper also reported that Murdoch feels that the channel is 'BBC lite' and is 'dissatisfied' with Sky's staid presentation and 'liberal bias'.

Other indications of Murdoch's plans are readily available. For example, both BSkyB and News International used the consultation process leading up to the Communications Bill to lobby for relaxation of the current broadcasting content regulations, and their submissions are easily viewable on the Department of Culture, Media and Sport's website. Or turn to a recent edition of the British Journalism Review to find Sun pundit Richard Littlejohn complaining that whilst at Sky News 'we'd never been able to make the programme we intended. If Sky News could emulate its US sister Fox News, which has wiped the floor with CNN with opinion-driven "fair and balanced" coverage, ratings would soon shoot past the Astra satellite. But the regulators won't allow it'. Littlejohn has just returned to Sky News with his own talk show, produced by former Carlton executive Steve Clark who has been recruited to the channel specifically to give it greater edge and bite. The show has already attracted complaints to the ITC. Meanwhile Murdoch is starting news networks in Italy and India loosely modelled on Fox.

There is, of course, nothing remotely 'fair and balanced' about Fox News: in its very choice of pundits, interviewees and stories, quite apart from the way in which those stories are treated, it is, as FAIR puts it: 'the central hub of the conservative movement's well-oiled media machine'. In other words, it's just like Murdoch's papers. Take, for example, the way in which The Sunday Times used the publication of the IPPR and BSC/ITC studies shamelessly to lobby on behalf of its proprietor's interests. On 17 November it ran a piece by Andrew Sullivan headlined 'Let's hear it 
for prejudiced television news' and calling for 'an injection of honest bias, US-style'. Fox is represented as 'an antidote to the liberalism endemic to much of the rest of television', and the 'pseudo-objective networks' are condemned for their 'suffocating liberalism'. Turning to the UK, Sullivan complains that: 'nobody I knew in my generation who had anything good to say about Margaret Thatcher went into the BBC. Why should we be shocked today to find that, two decades later, news coverage reflects this view of the world?' He continues: 'watching the BBC when I visit Britain is an eye-opener. The soft anti-Americanism, the unreflective Third World-ism, the facile assumption that old-style statist politics on the environment are correct, the instinctual loathing of Israel, the benevolent multiculturalism, the equation of the European Union with the future all reflect an effortless left-liberal viewpoint'. Sullivan concludes that whilst 'there's room for a leftleaning network in Britain ... what's wrong is the pretence that the BBC is somehow neutral, objective or balanced. And what makes this doubly wrong is that it's paid for by the licence fee. I can see why people in a free society should tolerate a television channel that promotes a viewpoint with which they disagree. I don't see why they should also be forced to pay for it and then be denied the opportunity to have an alternative by specious regulations over something ludicrously called balance'.

Few people would, I think, recognise the BBC from Sullivan's puerile caricature of it, but, of course, he has to peddle this kind of nonsense in order to put the argument that there needs to be an alternative news source to the BBC. This is exactly the kind of intellectually dishonest, self-serving twaddle that Fox News executives spout every time Fox is accused of being right wing. By tirelessly insisting that all other news providers are driven by liberal bias, they attempt the impossible intellectual conjuring trick of casting the rabid Fox as the centrist voice of reason. Thus John Moody, the channel's senior vice-president for news and editorial: 'there's a certain sameness to the news on the Big Three [networks] and CNN ... America is bad, corporations are bad, animal species should be protected, and every cop is a racist killer. That's where "fair and balanced" [Fox's slogan] comes in. We don't think all corporations are bad, every forest should be saved, every government spending programme is good. We're going to be more inquisitive'. Or as host of Only on Fox Tracy Gallagher put it: 'five years ago, Fox News Channel was launched on the idea that something was wrong in the news media - that somehow, somewhere bias found its way into reporting ... And it's not just the way you tell a story that can get in the way of the truth. It's the stories you choose to tell ... Fox News Channel is committed to being fair and balanced in the coverage of stories everybody is reporting - and to reporting stories you won't hear anywhere else. Stories you will see only on Fox'. Stories which are stories, however, only if viewed through the distorting lenses of a narrow, partisan and highly conservative news agenda, but stories whose 
absence from other media are then, of course, taken as further 'proof' of their allegedly liberal bias. The truth of the matter is, quite simply, that the mainstream media in the US appear overly-liberal only when viewed from a vertiginously conservative perspective. As FAIR point out, their ideology is, in fact, staunchly centrist, and rarely do they proselytise for left wing or even overtly progressive values. They do, however, like British broadcasters, try to uphold the traditional journalistic values of fairness, accuracy, independence of judgement and - yes - impartiality. Right wing journalism, on the other hand, seems to regard its mission in life as tirelessly to evangelise on behalf of the conservative world-view and to excoriate all unbelievers as the spawn of Satan. In other words, it's ‘journalism’ Daily Mail-style.

Can anyone seriously believe that the shortcomings of British television news and current affairs programmes are really going to be remedied by injecting the kind of brutishly populist news values which make Fox such a disgrace to broadcast journalism - and which have already given the UK some of the very worst newspapers in the world? Newspapers, by the way, whose readership has fallen by $25 \%$ in the last 40 years, and which, according to a recent Eurobarometer poll, are trusted by a mere $24 \%$ of the population.

The answer, apparently, is 'yes'. Thus, for example, Chris Shaw, controller of News and Current Affairs at C5 (which might soon be owned by Murdoch) wrote in The Times (which is of course owned by Murdoch) on 29 November 2002 that: 'the largely middle-class and liberal consensus on what constitutes impartiality helps to explain why TV news is so predictable and unadventurous and, more importantly, why TV news is growing less and less attractive to large cross-sections of the viewing audience'. In his view, given the sheer volume of news now available on television: 'the notion that all TV news on all channels should embrace an objective standard of impartiality and a common set of news values is simply not sustainable'. What is now needed are news programmes with 'more edge, distinction and character' and 'some genuine alternatives in terms of tone, approach and attitude'. He concludes that: 'TV news should be accurate, fair, honest and respectful of privacy, but that should not stop it from campaigning or pushing a particular agenda that concerns its audience. If a reporter should lie about, libel or racially insult someone, there are already laws to protect the victims. In short, TV news should have the same content regulation as newspapers'. That these are not exactly renowned for their effectiveness is conveniently ignored.

Meanwhile Roger Mosey, head of television news at the BBC, is quoted in the Guardian, 14 April 2003, to the effect that: 'in my personal view, the right way forward is to ensure that some clearly designated services have an obligation to truth, decency and the representation of a diversity of 
views; but the rest should have the freedom to take any view within the law of the land ... Setting some of the broadcasters free would encourage new voices and new perspectives, and it would offer real choices to consumers'. In this vision of things, presumably, Sky News would appeal to those wanting a televised version of the Sun, leaving BBC News 24 to clean up in the middle ground and other news channels to cater to political views not found on Sky.

This is all very well in theory, of course, but it completely ignores the realities of the media marketplace. These are all too clearly illustrated by the history of the British press since Murdoch's arrival. Thus when he took over the Sun he forced the Mirror to compete with it in the gutter, and when he plunged The Times downmarket the Telegraph inevitably began its descent into its present Liz Hurley-obsessed state. Ruthlessly predatory pricing, along with governmental connivance, did the rest. This is the 'success' story which Murdoch longs to repeat in broadcasting. A cash-drenched Sky News, plugging a relentlessly populist news agenda, adding its stentorian voice to the anti$\mathrm{BBC}$ bias of the Murdoch press, and bolstered by massive cross-media promotion from elsewhere in the Murdoch empire (including, quite probably, a Murdoch-owned C5), would rapidly force its way into a dominant position in the broadcast news environment. This is not, of course, because everyone would watch it; indeed, to many it would be as much an anathema as the Murdoch press. However, its sheer muscle, and its undoubted popularity with those sections of the audience actually wanting a British version of Fox News, would inevitably push others into trying to follow in its footsteps, whilst minority news channels would find the cost of entering such a skewed marketplace impossibly high. Meanwhile, the BBC and ITV news agendas, already far too prone to shadowing those of the press, would clearly risk being swept along in the populist and strident slipstream emanating from Sky. And if they didn't, then the Murdoch propaganda machine would always be reliably on hand to accuse them of liberal bias at the licence payers' expense.

\section{Julian Petley.}

An edited version of this paper appears in Index on Censorship, Vol.32, No.2, 2003. 